\title{
Estudo Comparativo entre Efedrina e Etilefrina como Vasopressor para Correção da Hipotensão Arterial Materna em Cesarianas Eletivas com Raquianestesia * Ephedrine and Etilefrine as Vasopressor to Correct Maternal Arterial
Hypotension during Elective Cesarean Section under Spinal
Anesthesia. Comparative Study
}

Sérgio D. Belzarena, TSA ${ }^{1}$

\section{RESUMO}

Belzarena SD - Estudo Comparativo entre Efedrina e Etilefrina como Vasopressor para Correção da Hipotensão Arterial Materna em Cesarianas Eletivas com Raquianestesia

JUSTIFICATIVA E OBJETIVOS: A efedrina é o vasopressor mais utilizado em obstetrícia e a etilefrina é muito usada em anestesia regional. $O$ objetivo deste estudo foi comparar a efedrina com a etilefrina para correção de hipotensão arterial materna durante raquianestesia para cesariana eletiva.

MÉTODO: Foram estudadas 120 gestantes divididas de forma aleatoria em dois grupos iguais. Todas receberam raquianestesia com bupivacaína, fentanil e morfina. Foi medida a pressão arterial não-invasiva e a freqüência cardíaca. Os recém-nascidos foram avaliados com o índice de Apgar. A incidência de hipotensão arterial, a quantidade de vasopressor necessária para correção e os efeitos adversos foram anotados.

RESULTADOS: Ocorreu hipotensão arterial materna com freqüência nos dois grupos, sendo $68 \%$ do grupo etilefrina e $63 \%$ do grupo efedrina. Na maioria das gestantes foi corrigida com a primeira dose do vasopressor, sem diferença entre os grupos (66\% etilefrina, $58 \%$ efedrina). A hipotensão arterial necessitou de duas ou mais doses de vasopressor para ser corrigida ou houve hipertensão reativa em poucas pacientes (24\% e $10 \%$ do grupo etilefrina e $34 \%$ e $8 \%$ do grupo efedrina, respectivamente) sem diferença estatística significativa. Não houve diferença nos efeitos adversos e nos testes dos recém-nascidos.

CONCLUSÕES: Com o método de administração empregado e com as doses de vasopressor selecionadas não houve diferença entre a efedrina e a etilefrina quando utilizadas para corrigir a hipotensão arterial materna em cesarianas com raquianestesia.

\footnotetext{
* Recebido (Received from) do Serviço de Anestesiologia da Santa Casa de Misericórdia de Santana do Livramento, Livramento, RS

1. Anestesiologista da Santa Casa de Misericórdia de Santana do Livramento, RS
}

Apresentado (Submitted) em 20 de julho de 2005

Aceito (Accepted) para publicação em 30 de janeiro de 2006

Endereço para correspondência (Correspondence to):

Dr. Sérgio D. Belzarena

Rua Jose Américo Domingues, 96

97574-710 Livramento, RS

E-mail: sbelza@adinet.com.uy

도 Sociedade Brasileira de Anestesiologia, 2006
Unitermos: ANESTESIA, Regional: raquianestesia; CIRURGIA, Obstétrica: cesariana; DROGAS: efedrina, etilefrina

\section{SUMMARY}

Belzarena SD - Ephedrine and Etilefrine as Vasopressor to Correct Maternal Arterial Hypotension during Elective Cesarean Section under Spinal Anesthesia. Comparative Study

BACKGROUND AND OBJECTIVES: Ephedrine is the most popular vasopressor for obstetrics and etilefrine is widely used in regional anesthesia. This study aimed at comparing ephedrine and etilefrine to correct maternal arterial hypotension during elective Cesarean section under spinal anesthesia.

METHODS: Participated in this study 120 pregnant patients who were randomly distributed in two equal groups. All patients received spinal anesthesia with bupivacaine, fentanyl and morphine. Noninvasive blood pressure and heart rate were monitored. Neonates were evaluated by the Apgar score. The incidence of hypotension, the amount of vasopressor needed to correct it and adverse effects were recorded.

RESULTS: Maternal hypotension was similar in both groups (68\% etilefrine group and $63 \%$ ephedrine group). The first vasopressor dose was enough to correct hypotension in most patients, with no difference between groups (66\% etilefrine, $58 \%$ ephedrine). Few patients needed two or more doses to correct hypotension or presented reactive hypertension $(24 \%$ and $10 \%$ in etilefrine and $34 \%$ and $8 \%$ in ephedrine groups, respectively), without statistically significant differences. There were no differences in adverse effects and neonate tests.

CONCLUSIONS: With the administration method and selected vasopressor doses, there have been no differences between ephedrine and etilefrine used to correct maternal hypotension during Cesarean section under spinal anesthesia.

Key Words: ANESTHESIA, Regional: spinal block; DRUGS: ephedrine, etilefrine; SURGERY, Obstetric: Cesarean section

\section{INTRODUÇÃO}

A hipotensão arterial pode ocorrer mesmo com expansão volêmica e o deslocamento do útero durante anestesia regional para cesariana e é tratada preferencialmente com vasopressores.

Um estudo tradicional, realizado em ovelhas, mostrou que a efedrina seria o fármaco de escolha para tratamento da 
hipotensão arterial na gravidez em comparação com outros vasopressores ${ }^{1}$. Modernamente, as conclusões deste estudo têm sido reconsideradas e fármacos com outros perfis farmacológicos também têm sido empregados, mostrando que no mínimo são tão eficazes quanto a efedrina, ou, ainda sugerindo que podem ter algumas vantagens ${ }^{2,3}$.

A etilefrina é bastante utilizada para correção da hipotensão arterial em anestesia regional ${ }^{4-7}$, mas não tem sido avaliada especificamente em obstetrícia.

O objetivo do presente estudo foi comparar a etilefrina com a efedrina para tratamento da hipotensão arterial em cesarianas.

\section{MÉTODO}

Após a aprovação pela Comissão de Ética da Santa Casa de Misericórdia de Livramento, foi obtido o consentimento esclarecido das pacientes para participar do estudo. Foram excluídas pacientes com hipertensão arterial preexistente ou doença hipertensiva da gravidez.

Cento e vinte pacientes submetidas à cesariana eletiva, fora do trabalho de parto, foram divididas de forma aleatória (de acordo com tabela gerada em computador) para receber efedrina ou etilefrina em caso de hipotensão arterial. A medicação vasopressora foi preparada diluindo-se em seringa de $10 \mathrm{~mL}$, ou seja, $9 \mathrm{~mL}$ de água destilada e $1 \mathrm{~mL}$ da ampola com $50 \mathrm{mg}$ de efedrina ou $10 \mathrm{mg}$ de etilefrina. A medicação foi preparada por uma enfermeira, que não participou do procedimento cirúrgico, antes que a paciente entrasse na sala cirúrgica.

Foi empregada a monitorização habitual, incluindo medida da $\mathrm{SpO}_{2}$, pressão automática não-invasiva (PANI) e ECG, e após venóclise foi instalada infusão de Ringer com lactato numa velocidade de 60 g.min ${ }^{-1}$. Não foi realizada expansão volêmica prévia e a anestesia realizada a seguir.

Em todos os casos foi realizada raquianestesia com a paciente na posição sentada, utilizando-se agulha 27G e administrando $10 \mathrm{mg}$ de bupivacaína a $0,5 \%$ hiperbárica, $20 \mu \mathrm{g}$ de fentanil e $100 \mu \mathrm{g}$ de morfina. Após a raquianestesia, a paciente ficou em decúbito dorsal e o útero foi deslocado manualmente.

A pressão arterial foi medida com o monitor automático Criticare 507 com a freqüência estabelecida em um minuto. A média das três primeiras aferições foi considerada a pressão inicial. O critério para definir hipotensão arterial foi a diminuição de $20 \mathrm{mmHg}$ da pressão sistólica ou média. $\mathrm{O}$ momento em que ocorreu diminuição da pressão arterial foi registrado. A hipotensão arterial foi tratada com $2 \mathrm{~mL}$ da solução por via venosa, adicionando-se infusão de $500 \mathrm{~mL}$ de Ringer com lactato com mais $4 \mathrm{~mL}$ da solução. Se ela não fosse corrigida em dois minutos, mais $2 \mathrm{~mL}$ da solução seriam administrados em bolus. Aumento de pressão arterial de mais de $20 \mathrm{mmHg}$ com relação à inicial foi considerado como hipertensão reativa e aumento da freqüência cardíaca acima de 110 bpm foi considerado como taquicardia reativa.

Náuseas ou vômitos foram tratados com 10 mg de metoclopramida e bradicardia (freqüência cardíaca igual ou inferior a $60 \mathrm{bpm}$ ) com 0,5 mg de atropina.
Foi medido o tempo entre o início da anestesia e o início da cirurgia e o tempo até a retirada do recém-nascido. Eles foram avaliados pelo pediatra da sala, considerando índice de Apgar maior ou igual a 8 , no $1^{\circ}$ e $5^{\circ}$ minutos, como crianças não-deprimidas.

A análise estatística dos dados colhidos foi feita com teste $t$ de Student para medidas contínuas e os dados categóricos foram analisados com o teste de Qui-quadrado. Valores de $p<0,05$ foram considerados como significativos.

\section{RESULTADOS}

Não houve diferença entre os grupos nas variáveis demográficas registradas (Tabela I).

A hipotensão arterial ocorreu com freqüência nas pacientes estudadas, ou seja, em 41 (68\%) das gestantes do grupo da etilefrina e 38 (63\%) das pacientes do grupo que recebeu efedrina, sem diferença estatística entre os grupos. $\mathrm{Na}$ maioria das gestantes dos dois grupos a diminuição da pressão arterial ocorreu após o bloqueio, mas algumas pacientes só apresentaram hipotensão arterial depois da retirada fetal, no momento do início da infusão de ocitocina (Tabela II).

A freqüência de correção da hipotensão arterial na primeira administração do vasopressor foi semelhante, sendo 27 (66\%) pacientes do grupo da etilefrina e 22 (58\%) do grupo da efedrina, o mesmo acontecendo com a incidência de hipertensão reativa em quatro (10\%) e três (8\%), respectivamente. A maioria das gestantes, em que foi necessário administrar mais vasopressor para corrigir a hipotensão arterial, retornou aos valores de pressão adequados na segunda dose. Ocorreu bradicardia em 12 (29\%) das pacientes do grupo etilefrina e em 14 (37\%) do grupo efedrina. Em praticamente todos os casos a diminuição da freqüência cardíaca foi simultânea com a diminuição da pressão arterial e melhorou com a administração do vasopressor. Somente três pacientes receberam atropina. Taquicardia ocorreu em poucas pacientes, em geral após a injeção do vasopressor, com curta duração. Não houve diferença na incidência de náusea e vômito (Tabela II).

Tabela I - Dados Demográficos

\begin{tabular}{lcc}
\hline & Grupo Etilefrina & Grupo Efedrina \\
\hline Idade \# & $33 \pm 5$ & $34 \pm 5$ \\
Peso \# & $74 \pm 11$ & $78 \pm 10$ \\
Altura \# & $159 \pm 9$ & $162 \pm 7$ \\
Primigestas * & 26 & 21 \\
Multigestas * $^{*}$ & 34 & 39 \\
\hline
\end{tabular}

* Valores expressos em número de pacientes.

\# Média \pm DP

Não houve diferença estatística entre os grupos. 


\section{ESTUDO COMPARATIVO ENTRE EFEDRINA E ETILEFRINA COMO VASOPRESSOR PARA CORREÇÃO DA HIPOTENSÃO ARTERIAL MATERNA EM CESARIANAS ELETIVAS COM RAQUIANESTESIA}

Tabela II - Características da Hipotensão Arterial e Efeitos Adversos

\begin{tabular}{lcc}
\hline & Grupo Etilefrina* & Grupo Efedrina * \\
\hline Sem hipotensão arterial & 19 & 22 \\
Com hipotensão arterial & 41 & 38 \\
Corrigida com a 1 ${ }^{\text {a }}$ dose & 27 & 22 \\
Não-corrigida & 10 & 13 \\
Hipertensão reativa & 4 & 3 \\
Taquicardia & 3 & 7 \\
Bradicardia & 12 & 14 \\
Náusea & 6 & 9 \\
Vômito & 3 & 2 \\
\hline
\end{tabular}

* Valores expressos em número de pacientes.

Não houve diferença estatística entre os grupos.

Os índices de Apgar registrados foram semelhantes nos recém-nascidos dos dois grupos. Dois recém-nascidos do grupo da etilefrina apresentaram Apgar menor que 8 no primeiro minuto, sendo que num dos casos a mãe não teve hipotensão arterial (Tabela III).

O tempo entre a injeção da solução subaracnóidea e o início da intervenção cirúrgica foi de $5 \pm 1$ minuto e o tempo até a retirada do recém-nascido foi de $9 \pm 3$ minutos desde a incisão cirúrgica. demonstrado que esta prática é ineficaz e pode ter efeitos deletérios para a mãe e para o feto ${ }^{8-11}$. O deslocamento do útero é importante para liberar o fluxo nas veias cava e aorta, sendo um complemento importante. Os vasopressores têm utilidade quando ocorre hipotensão arterial porque se sabe que a velocidade da correção traz benefícios maternos e fetais ${ }^{12,13}$. A recomendação para usar efedrina, inicialmente baseada em um estudo em ovelhas ${ }^{1}$, teve novos argumentos favoráveis quando outras importantes revelações apareceram na literatura. $\mathrm{O}$ primeiro artigo de Tong e Eisenach mostrou que a musculatura da artéria uterina tinha menor resposta contrátil frente à efedrina, com relação a outros vasopressores e este fato é útil para preservar o fluxo placentário ${ }^{13}$. Em um segundo artigo ${ }^{14}$, os mesmos autores demonstraram que, de maneira diferente de outros vasopressores, a efedrina, além de seu efeito vasoconstritor regional diminuído, libera óxido nítrico na artéria uterina e isto também pode facilitar o fluxo placentário.

No entanto, na gestante fora do trabalho de parto ocorreu hipotensão arterial com muita freqüência, variando a incidência nos diferentes estudos, mais por diferenças no método (na consideração de valores e na definição de hipotensão arterial) do que nas alterações tensionais registradas. Nos estudos em que o critério foi mais rígido, como o presente, a incidência de hipotensão arterial foi muito alta. Os registros foram superiores a $60 \%$ nos dois grupos, mostrando que o volume e o deslocamento são insuficientes e que a administração de vasopressor foi imprescindível na maioria das gestantes.

Como dado interessante, em algumas gestantes, a diminuição da pressão arterial só ocorreu depois da retirada do

Tabela III - Valores de Apgar e Peso dos Recém-Nascidos

\begin{tabular}{lcc} 
& Grupo Etilefrina & Grupo Efedrina \\
\hline Recém-nascidos (peso em g) \# & $3.321 \pm 416$ & $3.184 \pm 392$ \\
Apgar 1ㅇ minuto $<8^{*}$ & 2 & 1 \\
Apgar 1ㅇ minuto $\geq 8$ * & 58 & 59 \\
Apgar 5은 minuto $<8^{*}$ & 0 & 0 \\
Apgar 5o minuto $\geq 8$ * & 60 & 60 \\
\hline
\end{tabular}

* Valores expressos em número de recém-nascidos.

\# Média \pm DP

Não houve diferença estatística entre os grupos.

\section{DISCUSSÃO}

O principal resultado do estudo foi a ausência de diferenças no efeito de efedrina e etilefrina para tratar a hipotensão arterial, que ocorreu com freqüência quando se realizou raquianestesia para cesariana.

O tratamento da hipotensão arterial em obstetrícia esteve sempre vinculado à tríade expansão volêmica, deslocamento uterino e uso de vasopressores. Recentemente, tem sido questionada a prática de expandir previamente a volemia com grandes volumes, antes de iniciar a anestesia, porque foi feto, o que mostrou que a vigilância deve ser contínua e que o bloqueio simpático ocasionado pela anestesia regional tem um papel provavelmente tão importante quanto a compressão aortocava na geração da hipotensão arterial.

A pressão arterial voltou aos valores basais em $2 / 3$ das pacientes nos dois grupos, mas $1 / 3$ das gestantes precisou mais vasopressor ou apresentou hipertensão arterial. Esses dados mostraram, por um lado, um efeito semelhante entre os fármacos avaliados e, por outro, que ajustes na dose ou no modo de administração devem ser investigados para que se obtenham resultados mais consistentes. 
A hipotensão arterial foi acompanhada de diminuição da freqüência cardíaca em várias pacientes, o que também demonstrou a influência do bloqueio simpático na geração das alterações hemodinâmicas. A correção (e, em alguns casos, a ocorrência de taquicardia) mostrou o efeito do vasopressor e sugeriu que há efeitos próprios por ativação direta do receptor adrenérgico além daqueles que dependem exclusivamente da liberação de norepinefrina, embora essa liberação tenha maior importância. Esse dado foi sugerido também em um estudo experimental recente em animais ${ }^{15}$. Os recém-nascidos foram avaliados com o índice de Apgar, que é rotina no hospital. Um estudo recente em que são comparados valores do índice de Apgar com outros indicadores fetais (medidas de valores do sangue umbilical) mostrou em quase 300.000 recém-nascidos que o índice de Apgar tem o mesmo valor de previsão que a gasometria do sangue umbilical e que isto é aplicável tanto em recém-nascidos de termo como naqueles nascidos antes da $36^{\underline{a}}$ semana de gestação ${ }^{16}$. Como há outro estudo demonstrando que a incidência de acidose neonatal pode ser maior quando se usa efedrina ${ }^{17}$, poderia ser interessante realizar essa avaliação associando a medida dos gases umbilicais, lembrando que no último estudo citado participaram poucas pacientes. Outro elemento que também pode ter influenciado no resultado foi o tempo cirúrgico curto até a retirada fetal. Em conclusão, não houve diferenças entre etilefrina e efedrina, quando usadas da maneira apresentada, no tratamento de hipotensão arterial durante cesariana com raquianestesia. Dada a semelhança entre os fármacos e a diferença de custo, a etilefrina deve ser considerada uma alternativa como vasopressor em cirurgia obstétrica.

\section{Ephedrine and Etilefrine as Vasopressor to Correct Maternal Arterial Hypotension during Elective Cesarean Section under Spinal Anesthesia. Comparative Study}

\author{
Sérgio D. Belzarena, TSA, M.D.
}

\section{INTRODUCTION}

Arterial hypotension may be present even with volume expansion and uterine displacement during regional anesthesia for Cesarean section, and is preferably treated with vasopressors. A traditional study with ewes has shown that ephedrine was the drug of choice to treat hypotension during pregnancy as compared to other vasopressors ${ }^{1}$. Currently, the conclusions of this study are being reviewed and drugs with different pharmacological profiles are also being used, showing that they are at least as effective as ephedrine or even suggesting that the may present additional advantages ${ }^{2,3}$.
Etilefrine is widely used to correct hypotension during regional anesthesia ${ }^{4-7}$, but has not been specifically evaluated in obstetrics.

This study aimed at comparing etilefrine and ephedrine to treat hypotension during Cesarean section.

\section{METHODS}

After the Ethical Committee, Santa Casa de Misericórdia, Livramento approval and their informed consent, participated in this study 120 patients eligible for elective Cesarean section and not in labor, who were randomly distributed in two groups (according to computer-generated table) to receive ephedrine or etilefrine in case of hypotension. Exclusion criteria were patients with pre-existing hypertension or with pregnancy-induced hypertension. Vasopressor drugs were prepared by diluting in a $10 \mathrm{~mL}$ syringe, that is $9 \mathrm{~mL}$ distilled water and $1 \mathrm{~mL}$ of the vial with $50 \mathrm{mg}$ ephedrine or $10 \mathrm{mg}$ etilefrine. Medication was prepared by a nurse who has not participated in the surgical procedure and before the patient was referred to the operating room.

Monitoring consisted of $\mathrm{SpO}_{2}$, automatic noninvasive blood pressure (ANIP) and ECG. After venoclysis, lactated Ringer's infusion was started at the rate of $60 \mathrm{~g} \cdot \mathrm{min}^{-1}$. There has been no previous volume expansion and anesthesia was performed in sequence.

Spinal anesthesia was performed in all cases with patients in the sitting position with $27 \mathrm{G}$ needle and the administration of $10 \mathrm{mg}$ of $0.5 \%$ hyperbaric bupivacaine, $20 \mu \mathrm{g}$ fentanyl and 100 $\mu \mathrm{g}$ morphine. After spinal anesthesia, patients were placed in the supine position and the uterus was manually displaced. Blood pressure was measured with the automatic Criticare 507 monitor with frequency established in one minute. Initial pressure was defined as the mean of the first three measurements. Hypotension was defined as $20 \mathrm{mmHg}$ decrease in systolic or mean blood pressure. The moment in which blood pressure decreased was recorded. Hypotension was treated with $2 \mathrm{~mL}$ intravenous solution adding $500 \mathrm{~mL}$ lactated Ringer's infusion with additional $4 \mathrm{~mL}$ of the solution. If not corrected in 2 minutes, additional $2 \mathrm{~mL}$ of the solution were administered in bolus. Reactive hypertension was defined as blood pressure increase above $20 \mathrm{mmHg}$ of the initial pressure and increased heart rate above $110 \mathrm{bpm}$ was considered reactive tachycardia.

Nausea and vomiting were treated with $10 \mathrm{mg}$ metoclopramide and bradycardia (heart rate equal to or below $60 \mathrm{bpm}$ ) was treated with $0.5 \mathrm{mg}$ atropine.

Time between beginning of anesthesia and beginning of surgery and time for fetal extraction were recorded. The room pediatrician evaluated neonates, and those with Apgar scores equal to or above 8 at the $1^{\text {st }}$ and $5^{\text {th }}$ minutes were considered non-depressed.

Student's $t$ test was used for statistical analysis of continuous measures and Chi-square test was used for categorical data, considering significant $p<0.05$. 
EPHEDRINE AND ETILEFRINE AS VASOPRESSOR TO CORRECT MATERNAL ARTERIAL HYPOTENSION DURING ELECTIVE CESAREAN SECTION UNDER SPINAL ANESTHESIA. COMPARATIVE STUDY

Table I - Demographics Data

\begin{tabular}{lcc}
\hline & Etilefrine Group & Ephedrine Group \\
\hline Age \# & $33 \pm 5$ & $34 \pm 5$ \\
Weight \# & $74 \pm 11$ & $78 \pm 10$ \\
Height \# & $159 \pm 9$ & $162 \pm 7$ \\
Primiparous * & 26 & 21 \\
Multiparous * & 34 & 39 \\
\hline
\end{tabular}

* Values expressed in number of patients.

\# Mean \pm SD

No statistical differences between groups.

\section{RESULTS}

There were no differences between groups in demographics data (Table I).

Hypotension was frequent among studied patients, that is, 41 etilefrine group patients (68\%) and 38 ephedrine group patients $(63 \%)$, without statistical difference between groups. Blood pressure has decreased after blockade in most patients, but some patients have only presented hypotension after fetal extraction, when oxytocin infusion was started.

The frequency of hypotension correction with the first vasopressor dose was similar, being 27 (66\%) etilefrine group patients and $22(58 \%)$ ephedrine group patients, the same being true for the incidence of reactive hypertension, in $4(10 \%)$ and $3(8 \%)$ patients, respectively. Most patients in whom more vasopressor doses were needed to correct hypotension have returned to baseline values with the second dose. There has been bradycardia in $12(29 \%)$ etilefrine group patients and $14(37 \%)$ ephedrine group
Table II - Hypotension Profile and Adverse Effects

\begin{tabular}{lcc}
\hline & Etilefrine Group* & Ephedrine Group* \\
\hline Without hypotension & 19 & 22 \\
With hypotension & 41 & 38 \\
Corrected with the & 27 & 22 \\
$\quad 1^{\text {st }}$ dose & 10 & 13 \\
Uncorrected & 4 & 3 \\
Reactive hypertension & 3 & 7 \\
Tachycardia & 12 & 14 \\
Bradycardia & 6 & 9 \\
Nausea & 3 & 2 \\
Vomiting & 12 & \\
\hline
\end{tabular}

* Values expressed in number of patients.

No statistical differences between groups.

patients. In virtually all cases, heart rate decrease was simultaneous to blood pressure decrease and has improved with vasopressor administration. Only three patients received atropine. Tachycardia was present in few patients, in general after vasopressor administration and of short duration. There were no differences in the incidence of nausea and vomiting (Table II).

Apgar scores were similar for both groups. Two etilefrine group neonates presented Apgar score below 8 at the first minute and in one case the mother had no hypotension (Table III).

Time between spinal solution injection and beginning of the surgical procedure was $5 \pm 1$ minute and time until fetal extraction was $9 \pm 3$ minutes after surgical incision.

Table III - Neonates Apgar Scores and Weight

\begin{tabular}{lcc}
\hline & Etilefrine Group & Ephedrine Group \\
\hline Neonates (weight in $\mathrm{g}$ ) \# & $3,321 \pm 416$ & $3,184 \pm 392$ \\
Apgar $1^{\text {st }}$ minute $<8^{*}$ & 2 & 1 \\
Apgar $1^{\text {st }}$ minute $\geq 8$ * & 58 & 59 \\
Apgar $5^{\text {th }}$ minute $<8^{*}$ & 0 & 0 \\
Apgar $5^{\text {th }}$ minute $\geq 8$ * & 60 & 60 \\
\hline
\end{tabular}

* Values expressed in number of neonates.

\# Mean \pm SD

No statistical differences between groups.

\section{DISCUSSION}

The primary result of our study was the lack of differences between ephedrine and etilefrine to treat hypotension, which is frequent after spinal anesthesia for Cesarean section. The treatment of hypotension in obstetrics has always been linked to the triad volume expansion, uterine dis- placement and vasopressors. The practice of previously expanding volume with large volumes before inducing anesthesia has been recently questioned, because it has been shown that this practice is ineffective and may cause noxious effects to mother and fetus ${ }^{8-11}$. Uterine displacement is important to release cava and aorta flow. Vasopressors are useful in the presence of hypotension, 
because it is known that prompt correction brings maternal and fetal benefits ${ }^{12,13}$.

Ephedrine recommendation, firstly made by a study with ewes ${ }^{1}$, had new favorable arguments when other important revelations appeared in the literature. The first publication by Tong and Eisenach have shown that uterine artery muscles had lower contractile response to ephedrine as compared to other vasopressors and this is useful to preserve placental flow ${ }^{13}$. In a second article ${ }^{14}$ the same authors have shown that, differently from other vasopressors, ephedrine in addition to its decreased regional vasoconstrictor effect also releases nitric oxide in the uterine artery and this may also help placental flow.

However, hypotension is very frequent in pregnant patients not in labor and the incidence varies in different studies more due to differences in method (hypotension values and definition) than to recorded pressure changes. In studies with stricter criteria, such as this, the incidence of hypotension is very high. Records were above $60 \%$ in both groups, showing that volume and displacement are not enough, and that vasopressors are mandatory for most pregnant patients.

Interestingly, in some pregnant patients decreased blood pressure was only present after fetal extraction, showing that vigilance should be continuous and that regional anesthesiainduced sympathetic block has a role probably as important as the aorta-cava compression to generate hypotension.

Blood pressure has returned to baseline values in $2 / 3$ of patients of both groups, but $1 / 3$ of them needed additional vasopressor or presented hypertension. These data showed, on one hand a similar effect of both drugs, and on the other hand that dose adjustments or administration method should be investigated to obtain more consistent results.

Hypotension was followed by decreased heart rate in several patients, which has also shown the influence of sympathetic block on hemodynamic changes. Correction (and in some cases the presence of tachycardia) showed the vasopressor effect and suggested that there are peculiar effects by direct activation of the adrenergic receptor in addition to those exclusively depending on norepinephrine release, although this release is of major importance. These data were also suggested by a recent experimental animal study ${ }^{15}$.

Neonates were evaluated by the Apgar score, which is routine in our hospital. A recent study comparing Apgar scores to other fetal indicators (umbilical blood values) has shown in almost 300 thousand neonates that the Apgar score has the same predictive value of umbilical blood gases analysis and that this is applicable both to term neonates and those born before the $36^{\text {th }}$ week of gestation ${ }^{16}$. Since there is a different study showing that the incidence of neonatal acidosis may be higher with ephedrine ${ }^{17}$ it would be interesting to perform this evaluation associating umbilical blood gases analysis and reminding that few patients participated in the later study. Another element which might have influenced results was the short surgical time until fetal extraction.

In conclusion, with this model of study there were no differences between etilefrine and ephedrine used to treat hypotension during Cesarean section under spinal anesthesia. Given the similarities between drugs and the difference in cost, etilefrine should be considered an alternative vasopressor for obstetric procedures.

\section{REFERÊNCIAS - REFERENCES}

01. Ralston DH, Shnider SM, DeLorimier AA - Effects of equipotent ephedrine, metaraminol, mephentermine, and methoxamine on uterine blood flow in the pregnant ewe. Anesthesiology, 1974;40:354-370.

02. Ngan Kee WD, Lau TK, Khaw KS et al - Comparison of metaraminol and ephedrine infusions for maintaining arterial pressure during spinal anesthesia for elective cesarean section. Anesthesiology, 2001;95:307-313.

03. Lee A, Ngan Kee WD, Gin T - A quantitative, systematic review of randomized controlled trials of ephedrine versus phenylephrine for the management of hypotension during spinal anesthesia for cesarean delivery. Anesth Analg, 2002;94:920-926.

04. Glaser C, Marhofer P, Zimpfer G et al - Levobupivacaine versus racemic bupivacaine for spinal anesthesia. Anesth Analg, 2002;94:194-198.

05. Fanelli G, Borghi B, Casati A et al - Unilateral bupivacaine spinal anesthesia for outpatient knee arthroscopy. Can J Anaesth, 2000;47:746-751.

06. Leoni A, Magrin S, Mascotto G et al - Cervical plexus anesthesia for carotid endarterectomy: comparison of ropivacaine and mepivacaine. Can J Anaesth, 2000;47:185-187.

07. Casati A, Magistris L, Fanelli G et al - Small-dose clonidine prolongs postoperative analgesia after sciatic-femoral nerve block with $0.75 \%$ ropivacaine for foot surgery. Anesth Analg, 2000;91:388-392.

08. Rout CC, Akoojee SS, Rocke DA et al - Rapid administration of crystalloid preload does not decrease the incidence of hypotension after spinal anaesthesia for elective caesarean section. Br J Anaesth 1992;68:394-397.

09. Morgan PJ, Halpern SH, Tarshis J - The effects of an increase of central blood volume before spinal anesthesia for cesarean delivery: a qualitative systematic review. Anesth Analg, 2001;92:997-1005.

10. Rout CC, Rocke DA, Levin J et al - A reevaluation of the role of crystalloid preload in the prevention of hypotension associated with spinal anesthesia for elective cesarean section. Anesthesiology, 1993;79:262-269.

11. Corke BC, Datta S, Ostheimer GW et al - Spinal anaesthesia for Caesarean section. The influence of hypotension on neonatal outcome. Anaesthesia, 1982;37:658-662.

12. Datta S, Alper MH, Ostheimer GW et al - Method of ephedrine administration and nausea and hypotension during spinal anesthesia for cesarean section. Anesthesiology, 1982;56:68-70

13. Tong C, Eisenach JC - The vascular mechanism of ephedrine's beneficial effect on uterine perfusion during pregnancy. Anesthesiology 1992;76:792-798.

14. Li P, Tong C, Eisenach JC - Pregnancy and ephedrine increase the release of nitric oxide in ovine uterine arteries. Anesth Analg, 1996;82:288-293.

15. Kobayashi S, Endou M, Sakuraya F et al - The sympathomimetic actions of l-ephedrine and d-pseudoephedrine: direct receptor activation or norepinephrine release? Anesth Analg, 2003; 97:1239-1245.

16. Casey BM, McIntire DD, Leveno KJ - The continuing value of the Apgar score for the assessment of newborn infants. $N$ Engl $J$ Med, 2001;344:467-471. 


\section{EPHEDRINE AND ETILEFRINE AS VASOPRESSOR TO CORRECT MATERNAL ARTERIAL HYPOTENSION DURING ELECTIVE CESAREAN SECTION UNDER SPINAL ANESTHESIA. COMPARATIVE STUDY}

17. Cooper DW, Carpenter M, Mowbray $\mathrm{P}$ et al - Fetal and maternal effects of phenylephrine and ephedrine during spinal anesthesia for cesarean delivery. Anesthesiology, 2002;97:1582-1590.

\section{RESUMEN}

Belzarena SD - Estudio Comparativo entre Efedrina y Etilefrina como Vasopresor para Corrección de la Hipotensión Materna en Cesáreas Electivas con Raquianestesia

JUSTIFICATIVA Y OBJETIVOS: La efedrina es el vasopresor más utilizado en obstetricia y la etilefrina es muy usada en anestesia regional. El objetivo de este estudio fue el de comparar la efedrina con la etilefrina para la corrección de la hipotensión arterial materna durante raquianestesia para cesárea electiva.

MÉTODO: Se estudiaron 120 embarazadas divididas aleatoriamente en dos grupos iguales. Todas recibieron raquianestesia con bupivacaína, fentanil y morfina. Se les midió la presión arterial no invasiva y la frecuencia cardiaca. Los recién nacidos fueron eva- luados con el índice de Apgar. La incidencia de hipotensión arterial, la cantidad de vasopresor necesaria para corrección y los efectos adversos fueron registrados.

RESULTADOS: Ocurrió hipotensión arterial materna con frecuencia en los dos grupos, siendo un $68 \%$ del grupo etilefrina y un $63 \%$ del grupo efedrina. En la mayoría de las embrazadas, se corrigió con la primera dosis del vasopresor, sin diferencia entre los grupos (66\% etilefrina, 58\% efedrina). La hipotensión arterial necesitó dos o más dosis de vasopresor para ser corregida o se registró hipertensión reactiva en pocas pacientes (un $24 \%$ y un $10 \%$ del grupo etilefrina y $34 \%$ y $8 \%$ del grupo efedrina, respectivamente), sin diferencia estadística significativa. No hubo diferencia en los efectos adversos y en las pruebas de los recién nacidos.

CONCLUSIONES: Con el método de administración empleado y con las dosis de vasopresor seleccionadas no hubo diferencia entre la efedrina y la etilefrina cuando se utilizaron para corregir la hipotensión arterial materna en cesáreas con raquianestesia. 